\title{
Are orthobiologics the next chapter in clinical orthopedics? A literature review
}

\author{
Ortobiyoloji klinik ortopedinin sonraki bölümü mü? Bir literatür gözden geçirmesi
}

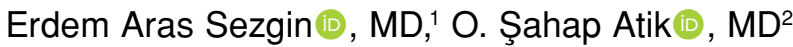 \\ 'Department of Orthopedics and Traumatology, Medicine Faculty of Gazi University, Ankara, Turkey \\ ${ }^{2}$ Professor of Orthopedic Surgery, Turkish Joint Diseases Foundation, Ankara, Turkey
}

\begin{abstract}
Orthobiologics are biologically derived materials which aim to promote healing and regeneration of tissues that are the focus of orthopedic surgery. Since bones, ligaments, tendons, and cartilage have different healing and regeneration characteristics, treatment strategies and clinical problems related to these tissues greatly differ. Although orthobiolgics are an old concept, most of the advancements in this field have been accomplished within the last two decades. A large number of promising laboratory studies show that orthobiolics hold a great potential in launching the next chapter of orthopedics. In this article, the use, research on this subject, future potential of orthobiologics, and the tissues in focus have been briefly reviewed.
\end{abstract}

Keywords: Augmentation; bone morphogenic protein; bone; cartilage; ligament; orthobiologics; platelet-rich plasma.

Orthobiologics are biologically derived materials which aim to promote regeneration of tissues that are the focus of orthopedic surgery. The biological characteristics of these materials rely on substances that are naturally present in blood. Urist et al. ${ }^{[1,2]}$ were one of the first to describe such a substance over 50 years ago, named bone morphogenic protein (BMP), which would assist bone regeneration. Discovery of BMPs paved the way for more and more research, in which an overwhelming amount of questions are still left unanswered. Meanwhile, impressive advancements have been introduced in the therapeutic use of orthobiologics over the last two
$\ddot{O} Z$

Ortobiyolojik malzemeler, ortopedik cerrahinin odağındaki dokuların iyileşmesini ve rejenerasyonunu destekleyen biyolojik olarak türetilmiş malzemelerdir. Kemiklerin, bağların, tendonların ve kıkırdağın herbirinin farklı iyileşme ve rejenerasyon özellikleri olması nedeniyle bu dokular ile ilişkili tedavi stratejileri ve klinik problemler de birbirinden oldukça farklıdır. Ortobiyoloji eski bir kavram olsa da, bu alandaki gelişmelerin büyük bir kısmı son iki onyıl içerisinde gerçekleşmiştir. Çok sayıda umut verici laboratuvar çalışması, ortobiyolojinin ortopedinin bir sonraki bölümünü başlatabilecek bir potansiyel taşıdığını göstermektedir. Bu yazıda, ortobiyoloji kullanımı, bu konudaki araştırmalar ve ortobiyolojinin gelecek potansiyeli odaktaki dokular kısaca için gözden geçirildi.

Anahtar sözcükler: Augmentasyon; kemik morfogenetik proteini; kemik; kıkırdak; bağ; ortobiyoloji; trombosit zengin plazma.

decades. Tissues of interest in orthobiologics include bone, ligament, tendon, and cartilage. In this article, we aimed to briefly review orthobiologics under titles of tissues in focus, discussing the current and future research on the topic and contemporary applications of orthobiolgics in clinical orthopedics.

\section{BONE}

Bones have the ability to regenerate after injury under ideal conditions. Most of the other tissues in the musculoskeletal system lack this ability of initial healing and remodelization into their original form. Despite this ability, fracture nonunion is and

Received: May 02, 2018 Accepted: May 19, 2018

Correspondence: Erdem Aras Sezgin, MD. Gazi Üniversitesi Tıp Fakültesi Ortopedi ve Travmatoloji Anabilim Dalı, 06500 Beşevler, Ankara, Turkey. Tel: +90 312 - 2025528 e-mail: easezgin@hotmail.com 
always has been one of the most troublesome clinical scenarios in orthopedics. In these cases, normal healing processes fail to regenerate new bone due to improper alignment, inadequate stability, circulatory problems, metabolic disorders, or critical-sized bone defects. Many materials and techniques have been developed to address these problems.

Bone grafting is one of the oldest and most studied techniques in orthobiologics. ${ }^{[3,4]}$ The three main concepts of the biology of bone grafting are osteoconduction, osteoinduction, and osteogenesis (Table I).

Osteoconduction is a passive process. These type of orthobiologics are used as porous scaffolds that usually mimic the formation of cancellous bone. Porous structure allows ingrowth of vascular tissue and mesenchymal stem cells (MSCs) that lead to bone ingrowth. ${ }^{[5]}$ The osteoinduction process aims to recruit pluripotent adult MSCs. These MSCs can then differentiate into osteoblasts and chondroblasts which have the ability to form new bone through endosteal ossification. ${ }^{[5]}$ Growth factors such as BMP and platelet-derived growth factor play a role in this process. New bone can be synthesized if a graft contains viable donor osteoblasts or their precursors. This process is called osteogenesis. ${ }^{[5]}$

Providing all three processes of osteoconduction, osteoinduction, osteogenesis while being histocompatible, autologous grafting is considered to be the gold standard orthobiologic material in bone healing. ${ }^{[5]}$ Critical-sized bone defects are one of the fields where orthobiologics are most necessary although autograft supply from the host is limited. In addition, donor site pain, increased blood loss, and operative time are other drawbacks. These drawbacks have influenced researchers to find alternatives to orthobiologics.

Allografts are processed grafts that originate from a human cadaver. Although this method is free of drawbacks associated with autografts, the sterilization process affects the biologic properties of allografts, limiting its osteoinductive and osteogenic properties. ${ }^{[5]}$ Other related drawbacks are the costs and risks of viral and bacterial transmission. Demineralized bone matrix (DBM) is a highly processed allograft which may retain osteoinductive potential ${ }^{[5]}$ and is created by demineralizing an allograft while still containing BMPs, collagen and other growth factors. Used in combination with a carrier, its clinical use is mostly in spine surgery as a bone graft extender, rather than a single effective orthobiologics solution. ${ }^{[6,7]}$ There are also reports on its use in ankle fusions and treatment of unicameral bone cysts in combination with autologous grafting. ${ }^{[8,9]}$

Autologous bone marrow aspirate is also a classical technique used to stimulate bone growth and angiogenesis. ${ }^{[6]}$ It is easily obtained from the iliac crest and is associated with fewer complications when compared to autologous grafts. ${ }^{[10]}$ Including MSCs and growth factors, it holds osteoinductive and osteogenic properties, although only 0.001 to $0.01 \%$ of the cells is MSC content. ${ }^{[11]}$ Therefore, it could be suggested that their osteoinductive properties are much more pronounced, containing significant amount of growth factors. ${ }^{[12]}$ Lacking osteoconductive properties, it is more effective when combined with allograft or ceramic scaffolds. New research shows that allogeneic MSCs can also be used effectively. One animal study suggested that they perform just as well as autologous MSCs in repairing bone while not initiating immune response. ${ }^{[13]}$ In an effort to overcome the challenges of using living MSCs, cell-free MSC-based products are gaining attention throughout the orthopedic research community. ${ }^{[14]}$ Cell-free techniques use MSCs, for obtaining a combination of growth factors secreted into a supernatant, so-called secretome. Secretome can then be collected as MSC-derived conditioned media (MSC-CM) or MSC-produced extracellular vesicles (MSC-EV), which have been shown to hold similar reparative capacities to MSCs themselves. ${ }^{[15,16]}$ Another method is based on using the extracellular

TABLE I

Orthobiologics for bone formation and their characteristics

\begin{tabular}{lccc}
\hline & Osteoconduction & Osteoinduction & Osteogenesis \\
\hline Autograft & + & + & + \\
Allograft & + & + & + \\
Bone marrow aspirate & & & + \\
Ceramics & + & + & + \\
Platelet-rich plasma & & + & + \\
Bone morphogenic protein & & & \\
\hline
\end{tabular}


matrix (ECM) and preserving its structural and bioactive elements after decellularization. ${ }^{[17]}$ Then, ECM can be used to enhance the basic properties of scaffolds. Moreover, ECM-coated titanium implants or ECM-polymer hybrid constructs are being studied in animals with promising results. ${ }^{[18]}$ In short, research on the cell-free strategies hold a great potential with the aim of introducing off-the-shelf therapeutic solutions with the potency of MSCs. ${ }^{[14]}$

Synthetic alternatives to autologous and allogeneic bone grafts are commonly used as "bone void fillers" due to their low cost and low-risk profile..$^{[5]}$ Tricalcium phosphate (TCP), calcium phosphate, and calcium sulfate are examples of these ceramic grafts. They are marketed in different forms from injectable to pellets or blocks. As they only act as osteoconductive materials, they are usually combined with other orthobiologics such as BMPs. ${ }^{[19-21]}$

Since the discovery of BMPs, 20 different types have been identified. They are a part of transforming growth factor- $\beta$ superfamily. ${ }^{[22]}$ Two of the BMPs (BMP-2 and BMP-7) have been approved by FDA and have been marketed for orthopedic use. Recombinant human BMP, BMP-7, however, was discontinued in 2014. They have been shown to be potent agents in bone formation through osteoinduction. ${ }^{[23]}$ Currently, the only FDA-approved indications are anterior lumbar interbody fusion and open tibial shaft fractures after intramedullary nailing. Though, success in BMPs off-label usage has also been reported in clinical practice when a large amount of bone needs to be replaced. In addition to fracture healing and arthrodesis fusion, orthobiologics, especially BMPs, are considered as coating materials for implants. ${ }^{[2,25]}$ Conventional implants have drawbacks associated with their unnatural characteristics such as nonintegration and infection. Animal models show that combinations of ceramic and biologic coatings including BMPs and other growth factors may lead to a solution to these problems. Despite the promising results of BMPs, numerous complications have also been reported, including heterotopic bone formation, wound complications due to seroma formation, and severe soft tissue swelling, carcinogenesis, being subject to dilution and losing effectiveness being soluble proteins. ${ }^{[22,26-28]}$ Another drawback associated with their use is that BMPs also lead to increased osteoclast formation which may result in graft resorption. ${ }^{[29]}$ To overcome this side effect, bisphosphonates are being investigated to be used in combination with BMPs. Reported results show that systemic or local bisphosphonates could be delivered by ceramic carriers in combination with
BMPs and result in an increased mineralized volume of neo-cortex and callus. ${ }^{[30,31]}$ Contemporary research reports contradicting results in animal studies. ${ }^{[32]}$ More data is necessary to determine accurate dosing and optimal delivery systems in order to prevent the aforementioned side-effects and expand their use.

Platelet-rich plasma (PRP) is derived from patients' complete blood and then centrifuged with various techniques to acquire growth factors such as platelet-derived growth factor (PDGF), transforming growth factor- $\beta 1$, epidermal growth factor (EGF), fibroblast growth factor (FGF), and insulin-like growth factor-1, with osteoinductive and osteogenic properties. Although lacking concrete evidence, when injected to the host, it has been suggested to enhance stem cell recruitment, angiogenesis, and extracellular matrix production. ${ }^{[33]}$ Despite its popularity in soft tissue problems, PRP's use in bone is rather limited. There are contradicting reports of its effectiveness, with most clinical studies failing to show improved clinical outcomes in spinal fusion or high tibial osteotomy. ${ }^{[34,35]}$ With uniform techniques for preparation and future research, PRP may be able to show its potential due to its high content of bioactive substances.

It is safe to assume that future research will shed more light on different strategies in orthobiologics for bone healing. Recombinant parathyroid hormone, teriparatide, is one of the promising candidates. Although it acts on osteoblasts and osteoclasts to resorb bone and increase serum calcium; it is shown that when administered in a pulsatile manner, it can increase bone mineral density and improve bone architecture. ${ }^{[36]}$ Another molecule of interest is Nel-like molecule-1 (NELL-1) which has been shown to enhance bone growth and repair in animal studies. ${ }^{[37]}$ It is believed to have a similar signaling cascade as BMPs and interacts with these proteins. ${ }^{[38]}$

\section{LIGAMENTS AND TENDONS}

Ligaments and tendons have similar construct thus, same or similar orthobiologics are used. Unlike bone, ligaments and tendons do not heal through regeneration but fibrous tissue formation. During repair, injured tissue is replaced by the newly synthesized matrix. In ideal conditions, a ligament or tendon can gain up to $60-70 \%$ of its original structure in six months but the repair process continues up to many years. ${ }^{[39]}$ Repair quality depends on the initial trauma, the gap between torn sides, and stability during repair. In an effort to maximize the efficiency of ligament and tendon repair, many methods of 
orthobiologics including biologic modulation, grafting, and other techniques such as gene therapy are being studied extensively.

Ideal conditions for healing are mostly nonexistent in one of the most common sports-related injury, the anterior cruciate ligament (ACL) tear, owing to its intracapsular position. Therefore ligament reconstruction techniques are considered to be the gold standard treatment for ACL tears. ${ }^{[40]}$ Let aside the current discussions about graft selection and surgical technique, augmentation of the reconstruction is becoming more and more popular amongst orthopedic surgeons for their potential in better osteointegration in the graft-tunnel interface, faster recovery, and providing of better construct by enhancing ligamentization. The most studied orthobiologic augmentation is PRP, although literature fails to provide evidence to support its usage. There are studies that show no difference in clinical outcomes by addition of PRP. ${ }^{[41,42]}$ In a very recent systematic review investigating the usage of PRP, bone substitutes, calcium phosphate-hybridized grafts, and autologous stem cells, Hexter et al., ${ }^{[43]}$ concluded that most of the studies are preclinical and there is still a need for extensive clinical studies to support their use.

One of the most controversial topics on tendon healing is undoubtedly related to Achilles tendon rupture. There are numerous studies that suggest PRP augmentation after Achilles tendon repair results in faster recovery while as many which fail to show any benefits. ${ }^{[4-47]}$ Bone marrow aspirate concentrate was also tried with good results. ${ }^{[4]}$ Biologic matrix augmentation is another method of orthobiologics in Achilles tendon repair which offers increased repair strength and acts as a scaffold for cellular ingrowth. Its use is especially beneficial in chronic and complex injuries but there is still not enough evidence to conclude augmentation's superiority over traditional methods. ${ }^{[49]}$

The rotator cuff is another focus in orthobiologic augmentation. Platelet-rich plasma, biologic matrix augmentation, synthetic scaffolds, growth factors, and stem cells are the most studied topics in rotator cuff tears. In a very recent review, Charles et al ${ }^{[50]}$ concluded that overall consensus of current literature shows that PRP does not provide a benefit and is not cost effective. They also found that matrix augmentations instead provide mechanical reinforcement, lower re-tear rates, and better functional outcomes. Synthetic grafts alone were found to be unable to enhance ingrowth as well as matrix patches. They concluded that combination of matrix patches and growth factors may provide the best environment for repair, while MSC use still lacks evidence. Future research is channeled to tissue engineering with a focus on combination of nanofiber scaffolds and stem cells. ${ }^{[51]}$

Enthesis is a stress-transferring special interface, attaching ligament and tendon to bone. The human body is unable to generate the same enthesis after injury and healing results in a weaker biomechanical structure which is more susceptible to re-ruptures. Orthobiologics have been suggested to enhance healing. A recent review by Hexter et al. ${ }^{[52]}$ on the use of DBM to induce tendon-bone healing via enchondral ossification, similar to original enthesis, commented that available data on the topic relies on animal studies. Their conclusion was that although DBM shows potential in animal studies, in order to achieve significant improvements in enthesis healing, combinations of orthobiologics require further investigation. With clinical data on this topic, re-rupture problems after ACL reconstruction or rotator cuff repair may be significantly reduced.

\section{CARTILAGE}

Natural intrinsic healing capacity of articular cartilage is limited. Cartilage defects heal with scar tissue originating from subchondral bone and their structure is different to hyaline cartilage. Although it may result in short-term recovery, the load-bearing capacity of healing tissue is lower which results in early degeneration. With the goal of repairing tissue resembling hyaline cartilage, many techniques have been developed including microfracture, osteochondral autograft transplantation (OATS), autologous chondrocyte implantation (ACI), as well as osteochondral allografts. ${ }^{[53-56]}$ These techniques were developed two decades ago and there are reports that show good clinical results, however, they produce fibrocartilage and not hyaline cartilage. ${ }^{[57,58]}$ Therefore, new techniques of orthobiologics in cartilage repair are being studied extensively. Platelet-rich plasma is also a potential candidate in cartilage healing. An in vitro study showed the importance of leukocyte concentration of PRP and efficiency of delivery systems such as hydrogel in the treatment of cartilage damage. ${ }^{[59]}$ There is no evidence of its clinical use due to relevant literature being limited to several case reports. ${ }^{[60]}$

There have been many significant steps taken towards cartilage repair in the recent years by means of tissue engineering methods. One of these methods is chondrocyte-seeded scaffolds and matrix-induced ACI where donor site chondrocytes or MSCs are seeded into scaffolds made of hyaluronan-based, bio-resorbable 
polylactic-co-glycolic acid polymers or agarose-alginate hydrogels. ${ }^{[6]]}$ This cell-based scaffold is then sutured or glued to the recipient area. There are studies that focus on the use of growth factors such as TGF- $\beta 1$ and BMPs for enhancing chondrocyte expansion. This expansion is necessary to increase the number of chondrocytes and their ECM deposition, therefore, achieving biochemical integrity. ${ }^{[6]]}$ Mechanical loads or hypoxia are also necessary to stimulate chondrocytes. ${ }^{[62,63]}$ Stem cells are also used with these tissue engineering methods, which is free of risks associated with autologous chondrocyte usage. Although positive results are being reported in the pre-clinical setup, more clinical data is required in order to make a conclusion on this new concept. In addition, complex regulatory requirements are one of the reasons to slow down the advancement of cellular therapies. ${ }^{[64]}$

\section{Conclusion}

In spite of being a rather old concept, research on orthobiologics is richer and more accelerated than it has ever been. Current clinical experience on orthobiologics should be regarded as first steps taken into the new concept of musculoskeletal system healing. Contemporary animal studies, advances in tissue engineering, and material science, joined by supporting evidence of clinical effectiveness show that orthobiologics holds a great potential to unfold a new chapter in clinical orthopedics.

\section{Declaration of conflicting interests}

The authors declared no conflicts of interest with respect to the authorship and/or publication of this article.

\section{Funding}

The authors received no financial support for the research and/or authorship of this article.

\section{REFERENCES}

1. Urist MR. Bone: formation by autoinduction. Science 1965;150:893-9.

2. Urist MR, Silverman BF, Büring $K$, Dubuc FL, Rosenberg JM. The bone induction principle. Clin Orthop Relat Res 1967;53:243-83.

3. M'gregor AN. The Repair of Bone, with special reference to Transplantation and other Artificial Aids. J Anat Physiol 1892;26:220-30.

4. Janeway HH. V. Autoplastic Transplantation of Bone. Ann Surg 1910;52:217-28.

5. Roberts TT, Rosenbaum AJ. Bone grafts, bone substitutes and orthobiologics: the bridge between basic science and clinical advancements in fracture healing. Organogenesis 2012;8:114-24.

6. Ajiboye RM, Eckardt MA, Hamamoto JT, Plotkin B, Daubs MD, Wang JC. Outcomes of Demineralized Bone Matrix Enriched with Concentrated Bone Marrow Aspirate in Lumbar Fusion. Int J Spine Surg 2016;10:35.
7. Duarte RM, Varanda P, Reis RL, Duarte ARC, Correia-Pinto J. Biomaterials and Bioactive Agents in Spinal Fusion. Tissue Eng Part B Rev 2017;23:540-51.

8. Wee J, Thevendran G. The role of orthobiologics in foot and ankle surgery: Allogenic bone grafts and bone graft substitutes. EFORT Open Rev2017;2:272-80.

9. Perisano C, Rosa MA, Donati F, Barone C, Maccauro G. Treatment options of simple bone cysts: the role of bone substitutes, growth factors and literature review. J Biol Regul Homeost Agents 2016;30:159-64.

10. Bierman HR. Bone marrow aspiration the posterior iliac crest, an additional safe site. Calif Med.1952;77:138-9.

11. Pittenger MF, Mackay AM, Beck SC, Jaiswal RK, Douglas R, Mosca JD, et al. Multilineage potential of adult human mesenchymal stem cells. Science 1999;284:143-7.

12. McCarrel T, Fortier L. Temporal growth factor release from platelet-rich plasma, trehalose lyophilized platelets, and bone marrow aspirate and their effect on tendon and ligament gene expression. J Orthop Res 2009;27:1033-42.

13. Charron D, Suberbielle-Boissel C, Tamouza R, Al-Daccak R. Anti-HLA antibodies in regenerative medicine stem cell therapy. Hum Immunol 2012;73:1287-94.

14. Haumer A, Bourgine PE, Occhetta P, Born G, Tasso R, Martin I. Delivery of cellular factors to regulate bone healing. Adv Drug Deliv Rev 2018;129:285-94.

15. Koniusz S, Andrzejewska A, Muraca M, Srivastava AK, Janowski M, Lukomska B. Extracellular vesicles in physiology, pathology, and therapy of the immune and central nervous system, with focus on extracellular vesicles derived from mesenchymal stem cells as therapeutic tools. Front Cell Neurosci 2016;10:109.

16. Xie H, Wang Z, Zhang L, Lei Q, Zhao A, Wang H, et al. Extracellular vesicle-functionalized decalcified bone matrix scaffolds with enhanced pro-angiogenic and probone regeneration Activities Sci Rep 2017;7:45622.

17. Bourgine PE, Pippenger BE, Todorov A Jr, Tchang L, Martin I. Tissue decellularization by activation of programmed cell death. Biomaterials 2013;34:6099-108.

18. Sadr N, Pippenger BE, Scherberich A, Wendt D, Mantero S, Martin I, et al. Enhancing the biological performance of synthetic polymeric materials by decoration with engineered, decellularized extracellular matrix. Biomaterials 2012;33:5085-93.

19. Horstmann PF, Raina DB, Isaksson $H$, Hettwer W, Lidgren L, Petersen MM, et al. Composite biomaterial as a carrier for bone-active substances for metaphyseal tibial bone defect reconstruction in rats. Tissue Eng Part A 2017;23:1403-12.

20. Sirka A, Raina DB, Isaksson H, Tanner KE, Smailys A, Kumar A, et al. Calcium sulphate/hydroxyapatite carrier for bone formation in the femoral neck of osteoporotic rats. Tissue Eng Part A 2018 Jun 1.

21. Bae EB, Park KH, Shim JH, Chung HY, Choi JW, Lee JJ, et al. Efficacy of rhBMP-2 loaded PCL/ $\beta$-TCP/bdECM scaffold fabricated by $3 \mathrm{D}$ printing technology on bone regeneration. Biomed Res Int 2018;2018:2876135.

22. Finkemeier CG. Bone-grafting and bone-graft substitutes. J Bone Joint Surg [Am] 2002;84:454-64.

23. Wozney JM, Rosen V. Bone morphogenetic protein and bone morphogenetic protein gene family in bone formation and repair. Clin Orthop Relat Res 1998;346:26-37. 
24. Goodman SB, Yao Z, Keeney M, Yang F. The future of biologic coatings for orthopaedic implants. Biomaterials 2013;34:3174-83.

25. Junker R, Dimakis A, Thoneick M, Jansen JA. Effects of implant surface coatings and composition on bone integration: a systematic review. Clin Oral Implants Res 2009;20:185-206.

26. Tian H, Zhao J, Brochmann EJ, Wang JC, Murray SS. Bone morphogenetic protein-2 and tumor growth: Diverse effects and possibilities for therapy. Cytokine Growth Factor Rev 2017;34:73-91.

27. Shi L, Sun W, Gao F, Cheng L, Li Z. Heterotopic ossification related to the use of recombinant human BMP-2 in osteonecrosis of femoral head. Medicine (Baltimore) 2017;96:e7413.

28. Chan DS, Garland J, Infante A, Sanders RW, Sagi HC. Wound complications associated with bone morphogenetic protein-2 in orthopaedic trauma surgery. J Orthop Trauma 2014;28:599-604

29. Kaneko H, Arakawa T, Mano H, Kaneda T, Ogasawara A, Nakagawa M, et al. Direct stimulation of osteoclastic bone resorption by bone morphogenetic protein (BMP)-2 and expression of BMP receptors in mature osteoclasts. Bone 2000;27:479-86.

30. Zwolak P, Farei-Campagna J, Jentzsch T, von Rechenberg $B$, Werner CM. Local effect of zoledronic acid on new bone formation in posterolateral spinal fusion with demineralized bone matrix in a murine model. Arch Orthop Trauma Surg 2018;138:13-8.

31. Raina DB, Isaksson $H$, Hettwer W, Kumar A, Lidgren L, Tägil M. A Biphasic calcium sulphate/hydroxyapatite carrier containing bone morphogenic protein-2 and zoledronic acid generates bone. Sci Rep 2016;6:26033.

32. Cleemann R, Bechtold JE, Sorensen M, Soballe K, Baas J. Dose-dependent resorption of allograft by rhBMP2 uncompensated by new bone formation-a canine study with implants and zoledronate. J Arthroplasty 2018;33:1215-21.

33. Hsu WK, Mishra A, Rodeo SR, Fu F, Terry MA, Randelli $\mathrm{P}$, et al. Platelet-rich plasma in orthopaedic applications: evidence-based recommendations for treatment. J Am Acad Orthop Surg 2013;21:739-48.

34. Carreon LY, Glassman SD, Anekstein Y, Puno RM. Platelet gel (AGF) fails to increase fusion rates in instrumented posterolateral fusions. Spine (Phila Pa 1976) 2005;30:243-6.

35. Dallari D, Savarino L, Stagni C, Cenni E, Cenacchi A, Fornasari PM, et al. Enhanced tibial osteotomy healing with use of bone grafts supplemented with platelet gel or platelet gel and bone marrow stromal cells. J Bone Joint Surg [Am] 2007;89:2413-20.

36. Tella SH, Gallagher JC. Biological agents in management of osteoporosis. Eur J Clin Pharmacol 2014;70:1291-301.

37. Li W, Zara JN, Siu RK, Lee M, Aghaloo T, Zhang $X$, et al. Nell-1 enhances bone regeneration in a rat criticalsized femoral segmental defect model. Plast Reconstr Surg 2011;127:580-7.

38. Truong T, Zhang X, Pathmanathan D, Soo C, Ting K. Craniosynostosis-associated gene nell-1 is regulated by runx2. J Bone Miner Res 2007;22:7-18.

39. Bray RC, Rangayyan RM, Frank CB. Normal and healing ligament vascularity: a quantitive histological assessment in the adult rabbit medial collateral ligament.
J Anat 1996;188:87-95.

40. Mehran N, Moutzouros VB, Bedi A. A review of current graft options for anterior cruciate ligament reconstruction. JBJS Rev 2015;3.

41. Figueroa D, Figueroa F, Calvo R, Vaisman A, Ahumada X, Arellano S. Platelet-rich plasma use in anterior cruciate ligament surgery: systematic review of the literature. Arthroscopy 2015;31:981-8.

42. Silva A, Sampaio R. Anatomic ACL reconstruction: does the platelet-rich plasma accelerate tendon healing? Knee Surg Sports Traumatol Arthrosc 2009;17:676-82.

43. Hexter AT, Thangarajah T, Blunn G, Haddad FS. Biological augmentation of graft healing in anterior cruciate ligament reconstruction. Bone Joint J 2018;100-B:271-84.

44. Zou J, Mo X, Shi Z, Li T, Xue J, Mei G, et al. A prospective study of platelet-rich plasma as biological augmentation for acute achilles tendon rupture repair. Biomed Res Int 2016;2016:9364170.

45. Sánchez M, Anitua E, Azofra J, Andía I, Padilla S, Mujika I. Comparison of surgically repaired Achilles tendon tears using platelet-rich fibrin matrices. Am J Sports Med 2007;35:245-51.

46. Sadoghi P, Rosso C, Valderrabano V, Leithner A, Vavken $\mathrm{P}$. The role of platelets in the treatment of Achilles tendon injuries. J Orthop Res 2013;31:111-8.

47. Schepull T, Kvist J, Norrman H, Trinks M, Berlin G, Aspenberg P. Autologous platelets have no effect on the healing of human achilles tendon ruptures: a randomized single-blind study. Am J Sports Med 2011;39:38-47.

48. Stein BE, Stroh DA, Schon LC. Outcomes of acute Achilles tendon rupture repair with bone marrow aspirate concentrate augmentation. Int Orthop 2015;39:901-5.

49. Anaim AA. Use of a non-crosslinked porcine dermal matrix in repair of the achilles and other tendons of the foot. Foot Ankle Spec 2018:1938640017751189.

50. Charles MD, Christian DR, Cole BJ. The Role of Biologic Therapy in Rotator Cuff Tears and Repairs. Curr Rev Musculoskelet Med 2018;11:150-61.

51. Patel S, Gualtieri AP, Lu HH, Levine WN. Advances in biologic augmentation for rotator cuff repair. Ann N Y Acad Sci 2016;1383:97-114.

52. Hexter AT, Pendegrass C, Haddad F, Blunn G. Demineralized bone matrix to augment tendon-bone healing: a systematic review. Orthop J Sports Med 2017;5:2325967117734517.

53. Atik OS, Takka S, Satana T, Kanatlı U, Bayar A, Şenköylü A. Osteochondral multiple autograft transfer. Eklem Hastalik Cerrahisi 1996;13:1-2.

54. Atik OS, Uslu MM, Eksioglu F. Osteochondral multiple autograft transfer (OMAT) for the treatment of cartilage defects in the knee joint. Bull Hosp Jt Dis 2005;63:37-40.

55. Hangody L, Kish G, Kárpáti Z, Udvarhelyi I, Szigeti I, Bély M. Mosaicplasty for the treatment of articular cartilage defects: application in clinical practice. Orthopedics 1998;21:751-6.

56. Steadman JR, Rodkey WG, Briggs KK. Microfracture to treat full-thickness chondral defects: surgical technique, rehabilitation, and outcomes. J Knee Surg 2002;15:170-6.

57. Van Assche D, Staes F, Van Caspel D, Vanlauwe J, Bellemans J, Saris DB, et al. Autologous chondrocyte implantation versus microfracture for knee cartilage injury: a prospective randomized trial, with 2-year follow-up. Knee Surg Sports Traumatol Arthrosc 2010;18:486-95. 
58. Bentley G, Biant LC, Vijayan S, Macmull S, Skinner JA, Carrington RW. Minimum ten-year results of a prospective randomised study of autologous chondrocyte implantation versus mosaicplasty for symptomatic articular cartilage lesions of the knee. J Bone Joint Surg [Br] 2012;94:504-9.

59. Yaşar Şirin D, Yılmaz İ, İsyar M, Öznam K, Mahiroğulları M. Does leukocyte-poor or leukocyte-rich platelet-rich plasma applied with biopolymers have superiority to conventional platelet-rich plasma applications on chondrocyte proliferation? Eklem Hastalik Cerrahisi 2017;28:142-51.

60. Atik OŞ. Platelet-rich plasma: Everything new may not be good enough! Eklem Hastalik Cerrahisi 2017;28:63.
61. Huang BJ, Hu JC, Athanasiou KA. Cell-based tissue engineering strategies used in the clinical repair of articular cartilage. Biomaterials 2016;98:1-22.

62. Jeon JE, Schrobback K, Hutmacher DW, Klein TJ. Dynamic compression improves biosynthesis of human zonal chondrocytes from osteoarthritis patients. Osteoarthritis Cartilage 2012;20:906-15.

63. Meretoja VV, Dahlin RL, Wright S, Kasper FK, Mikos AG. The effect of hypoxia on the chondrogenic differentiation of co-cultured articular chondrocytes and mesenchymal stem cells in scaffolds. Biomaterials 2013;34:4266-73.

64. Bongso A, Lee EH. Stem cells: From bench to bedside. 2nd ed. Singapore: World Scientific Publishing Company; 2010. 